\title{
RAFAL MAREK
}

Uniwersytet Łódzki, Wydział Filologiczny, Katedra Językoznawstwa Niemieckiego i Stosowanego, Zakład Językoznawstwa Niemieckiego

\section{Zapożyczenia a konotacja wyrazu - analiza na podstawie wybranych germanizmów we współczesnej polszczyźnie}

\section{Uwagi wstępne}

Leksyka jest tworem żywym, ciągle ulegającym różnorakim przemianom - jedne słowa stają się coraz rzadziej używane, inne stają się coraz częściej używane - świadczy to o tym, że język jest tworem żywym, podlegającym ciągłym zmianom. Taka właśnie sytuacja odnosi się do znaczenia wyrazów. Znaczenie wyrazów jest bowiem wartością zmienną w zależności od czasu oraz sytuacji, w jakich są one używane. Ta zasada dotyczy nie tylko słów rodzimych, lecz także wyrazów przejętych z innych języków obcych, czyli zapożyczeń.

Niniejsza praca porusza tematykę wpływu procesu zapożyczania obcojęzycznych elementów leksykalnych na konotację wyrazu - zjawisko to zostanie omówione na przykładzie niemieckich zapożyczeń leksykalnych w języku polskim. Tezy, stawiane w niniejszej pracy, zostaną podparte odpowiednimi egzemplifikacjami.

\section{0 konotacji wyrazu}

Omówienie problematyki wpływu zapożyczeń na konotację należy rozpocząć od zdefiniowania pojęcia konotacji wyrazu. Zjawisko konotacji badane jest w lingwistyce $\mathrm{z}$ wielu perspektyw [Bußmann 2002: 368] ${ }^{1}$. Według niemieckiego leksykologa, Thei Schippan, jako konotację wyrazu określa się dodatkowe

1 Tezy podane w niniejszym artykule pochodzą z niemieckojęzycznej literatury językoznawczej i zostały na potrzeby artykułu przetłumaczone przez Autora na język polski [przypis Autora]. 
elementy informacyjne, łączące się z danym leksemem i wykraczające poza jego znaczenia denotacyjne. Konotacja wskazuje na nadawcę, społeczne warunki lub zależne od określonej grupy społecznej sposoby użycia danych leksemów [Schippan 1984: 155]. Niemiecki językoznawca, Gerhard Helbig, rozumie konotację jako dodatkowe semantyczne, stylistyczne, emocjonalne, ekspresywne i oceniające elementy znaczeniowe, które ściśle korespondują ze znaczeniem podstawowym wyrazu (znaczeniem pojęciowym, denotacyjnym, denotacją). W niemieckojęzycznej literaturze z dziedzinie leksykologii można znaleźć także inne synonimiczne określenia na pojęcie konotacji: semantyka relacyjna (niem. Relationssemantik), znaczenie strukturalne (niem. Strukturbedeutung), Nebensinn, znaczenie afektywne, skojarzeniowe, okazjonalne (niem. affektive, assoziative, okkasionelle Bedeutung) [Schippan 1984: 156]. Do cech relacyjnych wyrazu można zaliczyć następujące elementy: walencję wyrazu, wartość uczuciową wyrazu, przestarzałość lub neologiczność danego wyrazu. Konotacja pełni następujące funkcje: wytwarzanie kontaktu między uczestnikami procesu komunikacji, przekazywanie dodatkowych informacji o zamiarze oraz przedmiocie procesu komunikacji.

Schippan wymienia osiem przyczyn konotacji wyrazu: emocjonalne, komunikacyjne, funkcyjne, społeczne, regionalne, czasowe, określone przez sytuację komunikacyjną oraz polityczno-ideologiczne uwarunkowania użycia danego wyrazu [Sikorska 2007: 69]. Emocjonalne nastawienie do denotatu wpływa na użycia zabarwionych stylistycznie elementów wypowiedzi (żartobliwe, ironiczne, pejoratywne konotacje etc.), np. żartobliwe (fachura 'potocznie o doświadczonym więźniu' (niem. Fachmann 'fachowiec') vs. doświadczony więzień, pingle 'potocznie o okularach', bryle 'potocznie o okularach' (niem. Brille 'okulary') - okulary, wlóczykijowanie 'żartobliwie o zamiłowaniu do włóczęgi' vs. zamitowanie do włóczegi), pejoratywne (bękart 'pejoratywnie o nieślubnym dziecku' (niem. Bankert 'pejoratywnie o nieślubnym dziecku') vs. nieślubne dziecko, breja 'pejoratywnie o mazi' (niem. Brei 'maź') vs. maź). Konotacja wpływa na sytuację, do której dany leksem jest adekwatny, np. potocznie - zwędzić 'potocznie: ukraść' (niem. entwenden 'ukraść') 'vs. ukraść, geszeft 'przestarzale o drobnym, zwykle nieuczciwym interesie' (niem. Geschäft 'interes') vs. interes, knajpa 'podrzędna restauracja' (niem. Kneipp 'restauracja') vs. restauracja [Sikorska 2007: 69]. Użycie wyrazu jest określone poprzez kategorię semantyczną, do której dany wyraz należy, co najlepiej da się zauważyć w przypadku słownictwa fachowego - można tutaj wyróżnić elementy leksykalne z takich dziedzin, jak muzyka - acapella 'bez akompaniamentu' (wł. a capella 'dosłownie: na sposób kościelny'), allegro 'wesoło' (wł. allegro 'wesoło'), medycyna-ekstrakcja 'usuwanie zęba lub soczewki oka' (łac. extractio 'wyciąganie'), narkoza 'uśpienie pacjenta za pomocą leków, wywołujących znieczulenie ogólne, także sen wywo-

${ }^{2}$ Niemieckie słowo entwenden zarezerwowane jest dla języka wyszukanego (tzw. Hochsprache - pol. język wysoki). 
łany w ten sposób' (gr. narkosis 'zamieranie'), sztuka - landszaft 1. 'pogardliwie o obrazie przedstawiającym małą wartość artystyczną' 2. 'przestarzale o obrazie przedstawiającym krajobrazy' (niem. Landschaft 'krajobraz'), leitmotiv 1. 'element treści, stylu, kompozycji dzieła literackiego lub muzycznego, przewijający się przez cały utwór, motyw przewodni', 2. 'coś, co ciągle powraca w jakiejś rozmowie, np. dany temat' (niem. Leitmotiv 'motyw przewodni') [Sikorska 2007: 69]. Społeczna konotacja wyrazu ściśle łączy się z jego przynależnością do danego socjolektu - w ten sposób znaczenie pojęciowe wyrazu nabiera konotacji społecznej [Schippan 1984: 156], np. ilustruje to język grupy uczniów - buda 'uczniowskie określenie szkoły' (niem. Bude 'buda') vs. szkota, dyro 'uczniowskie określenie dyrektora szkoły' vs. dyrektor, facetka 'uczniowskie określenie nauczycielki' vs. nauczycielka, Helga ${ }^{3}$ 'uczniowskie określenie nauczycielki języka niemieckiego' vs. nauczycielka niemieckiego. Konotacja odnosi się również do dialektalnego użycia wyrazów, np. kartofle 'regionalne określenia ziemniaka' (niem. Kartoffel 'ziemniak') vs. ziemniaki, bana 'gwarowe określenie pociągu' (niem. Bahn 'kolej') vs. pociag, sznylcug 'gwarowe określenie pociągu pospiesznego' (niem. Schnellzug 'pociąg pospieszny') vs. pociag pospieszny. Konotacja wyrazu wskazuje także na epoki historyczne, odległe czasy, np. hetman 'w Polsce przedrozbiorowej najwyższy dowódca wojsk' vs. Hauptmann 'dawniej: dowódca oddziału żołnierzy', ochmistrz 'w dawnej Polsce urzędnik zarządzający dworem króla lub magnata' vs. Hofmeister 'wychowawca i ceremoniarz na dworach' [Sikorska 2007: 70]. Konotacja sytuacyjna wyrazu może wyrażać się np. w formach trybu rozkazującego, np. szorujcie spać! vs., idźcie spać. Polityczno-ideologiczna odmiana konotacji polega na tym, że pojęcia o charakterze ogólnym, jak kapitalizm, państwo, np. w państwie socjalistycznym stają się konkretnie konotowanymi terminami [Sikorska 2007: 70].

\section{Zapożyczenia a konotacja wyrazu - analiza na podstawie wybranych germanizmów w polszczyźnie}

Podczas zapożyczenia wyrazu dochodzi często do zmian w obrębie struktury znaczeniowej wyrazu. Nie wszystkie komponenty znaczeniowe ulegają wtedy zmianom, lecz tylko niektóre. Ta reguła dotyczy konotacji wyrazu - wiele wyrazów zostaje zapożyczonych z języka obcego (języka dawcy) do ojczystego (języka biorcy $)^{4}$, by zapełnić luki występujące w leksyce. Niektóre zapożyczone słowa

\footnotetext{
${ }^{3}$ Uczniowskie określenie nauczycielki niemieckiego odnosi się do popularnego niemieckiego imienia żeńskiego - Helga.

${ }^{4}$ W niemieckojęzycznej literaturze dotyczącej tematyki zapożyczeń językowych język dawcy i biorcy określane są odpowiednio: Gebersprache i Nehmersprache [przyp. R. M.].
} 
są tożsame z przejętymi z innych kultur artefaktami, niewystępującymi w kulturze języka ojczystego - to odnosi się do egzotyzmów (np. w języku niemieckim Dollar 'nazwa waluty amerykańskiej', Duma 'nazwa rosyjskiego parlamentu', Masurka 'nazwa popularnego polskiego tańca ludowego z figurami, też: muzyka do tego tańca', Sejm 'izba niższa polskiego parlamentu, też: cały parlament'). W przeciwieństwie do egzotyzmów (i innych pożyczek, jak np. polskie burmistrz 'urzędnik stojący na czele władz danego miasta, też: urzędnik stojący na czele gminy, będącej częścią dużego miasta' (niem. Bürgermeister 'urzędnik stojący na czele gminy'), cech 'stowarzyszenie rzemieślników jednego lub kilku zawodów' (śrdk.-wys.-niem. zeche 'stowarzyszenie rzemieślników jednego lub kilku zawodów'), cegla 'materiał budowlany w postaci prostopadłościanu z gliny' (niem. Ziegel 'materiał budowlany w postaci prostopadłościanu z gliny'), mur 'ściana, ogrodzenie z kamieni, cegiel, betonu' (niem. Mauer 'ściana, ogrodzenie z kamieni, cegieł, betonu')) inne zapożyczenia różnicują wartość denotacyjną wyrazu. Zapożyczenia mogą nadać leksemom inną wartość konotacyjną. Poza neutralną konotacją można mówić o konotacji negatywnej, pozytywnej, zależnej od grupy społecznej, fachowej, dialektalnej i historycznej [Schippan 1984: 156].

Zależność między zapożyczeniem a konotacją wyrazu zostanie omówiona na przykładzie wybranych germanizmów w polszczyźnie. Znaczenie leksykalne niemieckich elementów w polszczyźnie uległo w procesie zapożyczenia licznym modyfikacjom. Poniżej zostały zestawione germanizmy w polszczyźnie wraz $\mathrm{z}$ ich pierwowzorami, by unaocznić zmiany w warstwie konotacyjnej wyrazu:

- konotacja emocjonalna - konotacja pejoratywna (danemu leksemowi przypisuje się negatywne komponenty znaczeniowe) - cwajer 'negatywna ocena w polskiej szkole - dwójka' vs. Zweier 'pozytywna ocena w niemieckiej szkole', cyc 'potocznie, pejoratywnie o kobiecej piersi' vs. Zitze 1. 'sutek', 2. 'dosadnie o sutku'; konotacja żartobliwa - bryle vs. Brille;

- sytuacje komunikacyjne - konotacja potoczna (leksemy używane w komunikacji codziennej, często ustnej) - fifka 'potocznie o rurce szklanej lub metalowej, używanej do palenia papierosów bezustnikowych' vs. Pfeife 'fajka', frajda 'potocznie o niezwykłej przyjemności, uciesze' vs. Freude 'radość', giwe$\boldsymbol{r a}$ 'potocznie o broni palnej, zwłaszcza o karabinie' vs. Gewehr 'karabin', graty 'rupiecie, rzeczy już nieużywane i niepotrzebne' vs. Geräte 'sprzęty, urządzenia, przyrządy', hajcować 'potocznie: ogrzewać' vs. heizen 'ogrzewać', pucować 'potocznie: myć, czyścić coś dokładnie' vs. putzen 'czyścić', rausz 'lekkie podniecenie lub odurzenie wywołane alkoholem' vs. Rausch 'upojenie, odurzenie, zamroczenie', saksy 'okresowa praca zarobkowa za granicą, dawniej tylko i wyłącznie w Niemczech' vs. Sachsen 'Saksonia - kraj związkowy w Niemczech ze stolicą w Lipsku', sznaps 'potocznie o kieliszku wódki' vs. Schnaps 'wódka', szrajbować 'potocznie: pisać' vs. schreiben 'pisać', trynknacc 'potocznie: napić się alkoholu' vs. trinken 'pić', zhaltować 'zatrzymać (o policji)' vs. anhalten 'zatrzymać'; 
- konotacja regionalna (leksemy są używane w danym regionie, są elementami danej gwary, dialektu) - bastlować 'majsterkować' vs. basteln 'majsterkować', futer 'karma, jedzenie' vs. Futter 'karma', gajgi 'skrzypce' vs. Geige 'skrzypce', nudle 'kluski' vs. Nudeln 'kluski', rychtyk 'prawda' vs. richtig 'prawda', szrank 'szafa' vs. Schrank'szafa';

- uwarunkowania społeczne (elementy leksykalne obrazujące grupy lub sytuacje społeczne) - np. elementy języka grup przestępczych - arbajtować 'pracować' vs. arbeiten 'pracować', bajtlować, 'żebrać' vs. betteln 'żebrać', tachować (się) 'śmiać się’ vs. lachen 'śmiać się', nemnąć 'wziąć' vs. nehmen 'wziąć', nie forta 'za wcześnie' vs. zu früh 'za wcześnie', wacha 'wodnista zupa'vs. Wasser 'woda';

- określenia historyczne (leksemy odnoszą się do konkretnego okresu, konkretnej epoki) - Führer 'tytuł Adolfa Hitlera jako głowy państwa niemieckiego', Gestapo 'policja polityczna, utworzona w 1933 r. po dojściu Hitlera do władzy, stanowiąca narzędzie terroru w Niemczech i krajach okupowanych; także funkcjonariusze tej policji', Stasi 'służba bezpieczeństwa w NRD'.

\section{Uwagi końcowe}

Podsumowując, występują ścisłe związki między zapożyczeniami a konotacją wyrazu. To świadczy o tym, że tylko niektóre komponenty znaczeniowe wyrazu podczas procesu zapożyczenia zostają przejęte przez język biorcy. Należy być w związku z tym świadomym, że zapożyczenia nie tylko prowadzą do wykształcenia się synonimów określeń już istniejących, lecz także zapełniają luki w systemie leksykalnym. Służy to rozwojowi systemu leksykalnego danego języka (tu: polskiego).

Niemieckie zapożyczenia leksykalne w polszczyźnie zajmują silną pozycję wśród innych zapożyczeń i w zdecydowanej mierze różnią się pod względem znaczeniowym od swoich niemieckich pierwowzorów - na podstawie powyższej analizy można sformułować wniosek, że różnice te dotyczą warstwy konotacyjnej, a także denotacyjnej wyrazu. Zapożyczone z języka niemieckiego leksemy w polszczyźnie najczęściej używane są potocznie, jako elementy języka fachowego, a także gwarowo.

\section{Bibliografia}

Bußmann H. (red.) [2002], Lexikon der Sprachwissenschaft, Alfred Kröner Verlag, Stuttgart.

Czerska U., Walewski S. (red.) [2005], Langenscheidt. Wielki stownik polsko-niemiecki, niemiecko-polski, Langenscheidt, Berlin i in.

Drabik L. (red.) [2012], Słownik wyrazów obcych z przykładami i poradami, Wydawnictwo Naukowe PWN, Warszawa. 
Horbatsch O. [1987], Deutsches Lehngut in polnischen Sondersprachen: Gauner-, Pennäler- und Soldatensprache, [w:] A. Pohl., A. de Vincenz (red.), Deutsch-polnische Sprachkontakte. Beiträge zur gleichnamigen Tagung 10.-13. April 1984 in Göttingen, Böhlau Verlag, Köln, Wien.

Kunkel-Razum K. [2006], Duden. Deutsches Universalwörterbuch, Dudenverlag, Mannheim.

Łaziński M. [2008], Słownik zapożyczeń niemieckich w polszczyźnie, Wydawnictwo Naukowe PWN, Warszawa.

Schippan Th. [1984], Lexikologie der deutschen Gegenwartssprache, VEB Bibliographisches Institut, Leipzig.

Sikorska K. [2007], Paradigmatische Bedeutungsrelationen im Wortfeld am Beispiel der Entlehnungen aus der Sachgruppe „Gefäße“ im Gegenwartspolnischen, [w:] W. Sadziński, M. Żytyńska (red.), Varietäten in deutscher Sprache und Literatur. Professor Roman Sadziński zu Seinem 60. Geburtstag gewidmet, Wydawnictwo Uniwersytetu Łódzkiego, Łódź.

Sobol E. (red.) [2012], Stownik języka polskiego, Wydawnictwo Naukowe PWN, Warszawa.

Tokarski J. (red.) [1980], Stownik wyrazów obcych, PWN, Warszawa. 